\title{
UNDERSTANDING THE PHENOMENON OF HAPPINESS \\ IN EXISTENTIAL PSYCHOLOGY
}

In Happiness And Contemporary Society : Conference Proceedings Volume (Lviv, March, 20-21, 2021). Lviv: SPOLOM, 2021. P. 145-147. https://doi.org/10.31108/7.2021.32

ISBN 978-966-919-697-2

\section{РОЗУМІННЯ ФЕНОМЕНУ ЩАСТЯ В ЕКЗИСТЕНЦІЙНІЙ ПСИХОЛОГІЇ}

// Щастя та сучасне суспільство : збірник матеріалів міжнародної наукової конференції (Львів, 20-21 березня 2021 р.). - Львів : СПОЛОМ, 2021. С. 145-147. https://doi.org/10.31108/7.2021.32

ISBN 978-966-919-697-2 


\section{KAPLUNENKO Yaryna}

$P h D$ in Psychology, Senior researcher

of I.O.Synytsya Laboratory of the psychology of studies,

G.S.Kostiuk Institute of Psychology of the National Academy of Educational Sciences of Ukraine. (Kyiv, Ukraine)

\section{UNDERSTANDING THE PHENOMENON OF HAPPINESS IN EXISTENTIAL PSYCHOLOGY}

The turbulent events of today, posing new challenges to humanity, in turn, actualize the negative effects and provoke the growth of people's mental tension, anxiety, depression, and crisis, moreover. In contrast, in recent years, there has been a tendency among scientists to understand and conceptualize the concepts of "psychological health" and "happiness", which correspond to the desire of philosophers and psychologists to form new guidelines for overcoming and preventing these negative influences. The article provides a brief historical and theoretical review of the understanding of the concept of happiness in the framework of existential psychology and psychotherapy from the point of view of leading representatives of this field, in particular, S. Kjerkegor, F. Nietzsche, E. Husserl, M. Heidegger, L. Binswanger, M. Boss, E. Van Deurzen, V. Frankl, A. Lengle.

KEY WORDS: the phenomenon of happiness, existential psychology, existence, being.

\section{КАПЛУНЕНКО Ярина}

кандидат психологічних наук, старший науковий співробітник Лабораторії психологї навчання імені І. О. Синичі

Інституту психології імені Г. С. Костюка НАПН Украӥни (Київ, Украӥна)

\section{РОЗУМІННЯ ФЕНОМЕНУ ЩАСТЯ В ЕКЗИСТЕНЦІЙНІЙ ПСИХОЛОГІЇ}

Буремні події сьогодення актуалізують нові виклики перед людством, посилюють негативні впливи та провокують зростання психічного напруження серед людей всього світу, й усіх верств населення. Рівень тривоги, стресу, депресивних настоїв стрімко зростає, спричиняючи виснаження, загальне почуття безрадісності, безвиході та беззмістовності. Драматичні загрози, катастрофи, кризи, втрати й згіршення, а також їх вплив на психологічне й фізичне здоров'я людей, зазвичай, привертають більше уваги дослідників, психологів та філософів, що закономірно та має еволюційне значення, оскільки на рефлекторному рівні ми швидше фокусуємося на джерелі загрози, щоб уникнути руйнування життя. Однак, як i будь яка рефлекторна реакція, цей природній фокус слугує швидше збереженню, але не формуванню, не збагаченню й розвитку життя, тому все більше релігійних діячів, психологів та філософів звертають увагу на концептуалізацію та осмислення поняття щастя. Що має на меті зформувати нові орієнтири для подолання та профілактики цих негативних впливів. 
3 давніх давен філософи зазначали, що прагнення до щастя природньо притаманне людині [1]. Категорія щастя $є$ центральною для давньогрецької та давньоримської думки: це й категорія моральної свідомості, й стан повного та тривалого задоволення життям, втіха, насолода, благоденство, добра доля, принцип моральної поведінки, найвище благо та наслідок доброго життя (Арістотель), відсутність пристрастей (Плутарх), відсутність страждань та незворушність (Діоген) [1]. Осмислення щастя продовжили християнські мислителі, вбачаючи найвище блаженство в єднанні з Богом або в переживанні Божественної любові, виділяючи при цьому внутрішне щастя та найвищу досконалість (Бл. Августин, Тома Аквінський). Французькі просвітителі ототожнювали щастя 3 доброю удачею (Вольтер), диференціювали обмежене щастя і щастя, що поширюється (Д. Дідро). I Кант вважав щастя поняттям, суб'єктивним та складним для визначення, наголошуючи на обмеженому характері цього переживання, що повністю підпорядковано царини природи. Ф. Гегель намагався розрізняти благоденство та щастя, називаючи останне не окремим задоволенням, яке виникає від відповідності між зовнішнім та внутрішнім, а безперервним станом, яке людина може створювати сама $(1,365-366)$.

Закорінюючись у філософську мудрість Древнього Риму, Греції, а також, Персії, Індії, Китаю та Японії, екзистенційна філософія, а згодом й екзистенційна психологія, також, намагалися знайти відповіді на віковічні питання: що є людське буття і як досягнути в ньому щастя? Продовжуючи традиції Сократа, Платона, Арістотеля, Епікура, Зенона на Заході та Зороастра, Будди, Конфуція, Лао-дзи на Сході, філософи - екзистенціалісти намагалися осмислити засадничі передумови наповненого та здійсненого людського життя.

Сформулювавши поняття « екзистенція» як внутрішне буття, яке поступово розкривається у зовнішнє, батько екзистенціальної філософії, Серен К'єркегор (1813-1855) зазначав відчай, який може відчувати людина, зраджуючи своїм засадничим внутрішнім цінностям, та можливість здійснення людиною свого буття в повноті лише через прийняття й налаштованість з Вселенським законом.

Фрідріх Ніцше (1844-1900), подібно до С. К'єркегора, намагався вийти за межі усталених форм філософії та по своєму осмислював людський шлях, вбачаючи його здійснення у звільненні від природних обумовленостей та реалізацію власного потенціалу, завдяки духовній трансформації, стійкості у стражданні та пошуку істини. Щастя він бачив у відчутті внутрішньої сили, подоланні обмежень та контролі власного життя й оточення.

Едмунд Гусерль (1859-1938) та Мартін Гайдегтер (1889-1976), заклавши фундамент феноменологічного підходу до пізнання та психотерапії, по різному концептуалізували поняття щастя, зазначаючи однак його цілісний характер, яке у Е. Гусерля набувало характеристик психологічно-морального переживання гармонійного самозадоволення, а у М. Гайдеггера було інтегральним феноменом пережиття єдності буття [2].

Поєднавши свою психоаналітичну практику з фундаментальною онтологією М. Гайдегтера, два швейцарських психіатра Людвіг Бінсвангер (1881-1966) та Медард Босс заклали фундамент першого системного підходу до екзистенційної психології й психотерапії. 3 точки зору Л. Бінсвангера, буття людини в світі обумовлюється їі світопроектом, що здебільшого підпорядкований зовнішньому 
контексту, але переживання, вираження та розуміння власного буття є змістом особистого самопроекту. Для Медарда Босса, людина існує як єдина, неподільна цілісність, що завжди розкривається як реальність, невід'ємна від взаємозв'язків буття. Розвиваючим налаштуванням $є$ сприйняття та відкритість, щоб мати справу 3 тим, що є, і з чим ми стикаємось. Присутність та наполегливість, які М. Босс виділяв як засадничі характеристики буття, притаманні лише людському існуванню, оскільки тільки людині властиве відкрите та вільне сприйняття[3].

Вихідною темою підходу Еммі Ван Дорцен, яскравої представниці британської екзистенційної школи, є розуміння життя як безкінечної боротьби, де моменти щастя швидше виключення, ніж правило, а отже, люди змушені зустрічатися зі своєю недосконалістю, протиріччями, та іншими викликами існування. Метою екзистенціальної терапії, з ії точки зору, є допомога у звільненні з безкінечного самообману та відчуження, та у заміні пошуку ілюзорного щастя, на відкриту зустріч 3 життєвими викликами та розкриття своїх талантів та можливостей [3].

Логотерапія, один з напрямків екзистенційної психотерапії, розроблена австрійським психіатром Віктором Франклом (1905-1997), спрямована на допомогу людині у віднайдені сенсу. Згідно В. Франклу, найглибшою мотивацією людини (глибшою за волю до насолоди та волю до влади) - жити змістовним життям, що $є$ протиотрутою до фрустрованості, безсенсовності, екзистенційної пустки та розпачу, що призводять до пригнічення, депресій та суїцидальних намірів. Щастя, за В. Франклом, не $\epsilon$ самоціллю, а швидше продуктом змістовного життя. Для життя, наповненого смислом, людині необхідно розвернутися до своїх деструктивних звичок, залежностей, настирливостей, фобій, щоб протидіяти їм та заповнити власний екзистенційний вакуум. 3 цією метою в межах цього підходу використовується ціла низка дидактичних прийомів та методів, від енергійного Сократівського діалогу до м'якого дослідження того, що радує та надихає людину.

Учень Віктора Франкла, Альфрід Ленгле, розширивши теорію та методологію Екзистенціного аналізу та логотерапії, бачить основну мету психотерапії у допомозі людям жити 3 «внутрішньою згодою» до того, що вони роблять. 3 його точки зору, це й $є$ шляхом до віднайдення щастя - «персонально» відчутна згода до всіх фундаментальних вимірів буття, що на практиці являють собою: прийняття данностей, звернення до цінностей, повага власного, свого та інших людей, і втілення значимого.

\section{ЛІТЕРАТУРА}

1. Європейський словник філософій: Лексикон неперекладностей - Том другий. Пер. 3 фр. -Том другий, К.: ДУХ І ЛІТЕРА, 2011. - 488 с.

2. Карівець І. Щастя з феноменологічного погляду. Едмунд Гусерль та Мартин Гайдегер // Щастя та сучасне суспільство : збірник матеріалів міжнародної наукової конференції (Львів, 20-21 березня 2020 р.). - Львів: СПОЛОМ, 2020. C. $129-131$.

3. The Wiley World Handbook of Existential therapy/ Editor(s):Emmy van Deurzen, Erik Craig, Alfried Längle, Kirk J. Schneider, Digby Tantam, Simon du Plock. USA: Wiley Blackwell, 2019. - 636 c. 